\title{
IQCJ/SCHIP1 Fusion Gene
}

National Cancer Institute

\section{Source}

National Cancer Institute. IQCIVSCHIP1 Fusion Gene. NCI Thesaurus. Code C99839.

A fusion gene $(\sim 2.5 \mathrm{~kb})$ that results from a read-through of 2 genes in the vicinity of 3q25.33 which fuses the IQCJ gene to the SCHIP1 gene. This read-through may be associated with axonal structure and function. 